\title{
PENINGKATAN KETERAMPILAN BERBICARA SISWA KELAS VII MTS NAHDLATUN NASYIIN KADUR DENGAN MENGGUNAKAN METODE NUMBERED HEADS TOGETHER (NHT) TAHUN PELAJARAN 2019/2020
}

\author{
Kusyairi \\ kusyairi@unira.ac.id \\ Fakultas Keguruan dan Ilmu Pendidikan, Universitas Madura
}

\begin{abstract}
Abstrak
Penggunaan metode NHT dalam pembelajaran keterampilan berbicara diharapkan mampu membawa siswa ke dalam situasi dan konteks berbahasa yang sesungguhnya sehingga keterampilan berbicara mampu melekat pada diri siswa sebagai sesuatu yang rasional, kognitif, emosional, dan afektif. Yang tidak kalah penting, para siswa juga akan mampu berkomunikasi secara efektif dan efisien sesuai dengan etika yang berlaku, baik secara lisan maupun tulis, mampu menghargai dan bangga menggunakan bahasa Indonesia sebagai bahasa persatuan dan bahasa negara, serta mampu memahami bahasa Indonesia dan menggunakannya dengan tepat dan kreatif untuk berbagai tujuan. Desain penelitian ini adalah desain penelitian tindakan kelas yang dilakukan dalam dua siklus, yakni siklus I dan siklus II. Subjek penelitian ini adalah siswa kelas VII MTs Nahdlatun Nasyiin Kadur dengan target pada siklus I dan siklus II adalah dengan nilai rata-rata 70. Pengumpulan data dalam penelitian ini menggunakan teknik tes dan nontes. Teknik tes berupa keterampilan berbicara dengan menggunakan metode NHT. Teknik nontes dalam penelitian ini berupa hasil observasi, angket, dokumentasi foto pada siswa kelas VII MTs Nahdlatun Nasyiin Kadur. Teknik analisis data dalam penelitian ini menggunakan teknik kuantitatif dan kualitatif. Kedua teknik tersebut dianalisis dengan membandingkan hasil tes siklus I dan siklus II. Berdasarkan hasil analisis, maka peneliti menyimpulkan bahwa nilai rata-rata kelas dalam persen pada saat siklus I adalah $64,88 \%$ dengan kategori cukup. Setelah dilakukan pembelajaran berbicara menggunakan pembelajaran kooperatif metode NHT siklus II, nilai ratarata siswa meningkat menjadi $80,00 \%$ dengan kategori baik. Bila diselisihkan, nilai rata-rata tersebut mengalami peningkatan sebesar $17,05 \%$ dan dapat diketegorikan peningkatan yang baik.
\end{abstract}

Kata kunci: Metode NHT, ketrampilan berbicara

\section{PENDAHULUAN}

Pendidikan adalah proses interaksi bertujuan, interaksi ini terjadi antara guru dan siswa, yang bertujuan meningkatkan perkembangan mental sehingga menjadi mandiri. Secara umum dapat dikatakan bahwa pendidikan merupakan satuan tindakan yang memungkinkan terjadinya belajar dan perkembangan (Dimyati, 1996:6). Pertumbuhan dan perkembangan peserta didik bergantung pada dua unsur yang saling mempengaruhi, yakni bakat yang dimiliki oleh peserta didik sejak lahir, dan lingkungan yang mempengaruhi hingga bakat itu tumbuh dan berkembang (Hamalik, 2003:3).

Pembelajaran bahasa Indonesia diarahkan untuk meningkatkan kemampuan peserta didik dalam berkomunikasi menggunakan bahasa Indonesia dengan baik dan benar, baik secara lisan maupun tulis, serta menumbuhkan apresiasi terhadap hasil karya kesastraan bangsa Indonesia. Standar kompetensi mata pelajaran bahasa Indonesia merupakan kualifikasi kemampuan minimal peserta didik yang menggambarkan penguasaan pengetahuan, keterampilan berbahasa, dan sikap positif terhadap bahasa dan sastra Indonesia. Standar kompetensi ini merupakan dasar bagi peserta didik untuk memahami dan merespon situasi lokal, regional, nasional, dan global. (Depag, 2004:103)

Salah satu aspek keterampilan berbahasa yang sangat penting peranannya 
dalam upaya melahirkan generasi masa depan yang cerdas, kritis, kreatif, dan berbudaya adalah keterampilan berbicara. Dengan menguasai keterampilan berbicara, peserta didik akan mampu mengekspresikan pikiran dan perasaannya secara cerdas sesuai konteks dan situasi pada saat dia sedang berbicara. Keterampilan berbicara juga akan mampu membentuk generasi masa depan yang kreatif sehingga mampu melahirkan tuturan atau ujaran yang komunikatif, jelas, runtut, dan mudah dipahami. Selain itu, keterampilan berbicara juga akan mampu melahirkan generasi masa depan yang kritis karena mereka memiliki kemampuan untuk mengekspresikan gagasan, pikiran, dan perasaan kepada orang lain secara runtut dan sistematis. Bahkan, keterampilan berbicara juga akan mampu melahirkan generasi masa depan yang berbudaya karena sudah terbiasa dan terlatih untuk berkomunikasi dengan pihak lain sesuai dengan konteks dan situasi tutur pada saat dia sedang berbicara. (Depag, 103:108)

Beberapa penelitian ditemukan bahwa pengajaran bahasa Indonesia telah menyimpang jauh dari misi sebenarnya. Guru lebih banyak berbicara tentang bahasa (talk about the language) daripada melatih menggunakan bahasa (using language). Dengan kata lain, yang ditekankan adalah penguasaan tentang bahasa (form-focus). Guru bahasa Indonesia lebih banyak berkutat dengan pengajaran tata bahasa, dibandingkan mengajarkan kemampuan berbahasa Indonesia secara nyata.

Salah satu pendekatan pembelajaran yang digunakan oleh guru untuk mewujudkan situasi pembelajaran yang kondusif; aktif, kreatif, efektif, dan menyenangkan adalah dengan metode Numbered Heads Together (NHT). Melalui Metode NHT, siswa diajak untuk berbicara dalam konteks dan situasi tutur yang nyata dengan menerapkan prinsip pemakaian bahasa secara komprehensif.
Penggunaan metode NHT dalam pembelajaran keterampilan berbicara diharapkan mampu membawa siswa ke dalam situasi dan konteks berbahasa yang sesungguhnya sehingga keterampilan berbicara mampu melekat pada diri siswa sebagai sesuatu yang rasional, kognitif, emosional, dan afektif. Yang tidak kalah penting, para siswa juga akan mampu berkomunikasi secara efektif dan efisien sesuai dengan etika yang berlaku, baik secara lisan maupun tulis, mampu menghargai dan bangga menggunakan bahasa Indonesia sebagai bahasa persatuan dan bahasa negara, serta mampu memahami bahasa Indonesia dan menggunakannya dengan tepat dan kreatif untuk berbagai tujuan.

Berdasarkan hasil observasi di MTs Nahdlatun Nasyiin Kadur menunjukkan bahwa keterampilan berbicara siswa kelas VII MTs Nahdlatun Nasyiin Kadur berada pada tingkat yang rendah, diksi (pilihan kata)-nya payah, kalimatnya tidak efektif, struktur tuturannya rancu, alur tuturannya pun tidak runtut dan kohesif. Ketika menjawab pertanyaan- pertanyaan yang diajukan oleh guru seringkali siswa hanya diam. Sebagian siswa dapat menjawab pertanyaan guru, namun hanya dengan jawaban singkat. Seringkali juga siswa ketika menjawab pertanyaan guru, namun menggunakan bahasa daerah (bahasa Madura). Para siswa mengalami kesulitan dalam mengekspresikan pikiran dan perasaannya secara lancar, membangun pola penalaran yang masuk akal, dan menjalin kontak mata dengan pihak lain secara komunikatif dan interaktif pada saat berbicara.

\section{Keterampilan Berbicara}

Kemampuan berbicara sangat penting dalam kehidupan manusia karena sebagian besar aktivitas kehidupan manusia membutuhkan dukungan kemampuan berbicara. Kemampuan berbicara telah diajarkan sejak siswa duduk di kelas I melalui pembelajaran 
keterampilan berbicara. Ketika siswa duduk di kelas IV sekolah dasar dan seterusnya, seharusnya siswa telah terampil berbicara.

Berbicara merupakan suatu proses penyampaian informasi, ide atau gagasan dari pembicara kepada pendengar. Si pembicara berdudukan sebagai komunikator sedangkan pendengar sebagai komunikan. Informasi yang disampaikan secara lisan dapat diterima oleh pendengar apabila pembicara mampu menyampaikannya dengan baik dan benar. Dengan demikian, kemampuan berbicara merupakan faktor yang sangat mempengaruhi kemahiran seseorang dalam penyampaian informasi secara lisan.

Sementara itu menurut Tarigan (1998:13) dengan menitikberatkan pada kemampuan pembicara menyatakan bahwa berbicara merupakan kemampuan mengucapkan bunyi-bunyi artikulasi terhadap kata-kata untuk mengekspresikan, menyatakan, serta menyampaikan pikiran, gagasan, dan perasaan. Sedangkan, sebagai bentuk atau wujudnya, berbicara dinyatakan sebagai suatu alat untuk mengomunikasikan gagasan-gagasan yang disusun serta dikembangkan sesuai dengan kebutuhankebutuhan sang pendengar atau penyimak.

Indikator penilaian berbicara dalam penelitian ini adalah sebagai berikut: (1) Intonasi dan Jeda yaitu pengaturan jeda, tinggi rendahnya nada, dan cepat lambatnya gaya berbicara. (2) Kesesuaian dengan topik yaitu materi yang dibicarakan harus sesuai dengan topik yang sudah ditentukan. (3) Pelafalan yaitu pelafalan kata secara jelas. (4) Gerak mimik yaitu keserasian antara ekspresi dengan wajah, gerak, sikap dan ucapan. (5) Volume suara yaitu keras lemahnya suara.

\section{Metode Numbered Heads Together (NHT)}

Salah satu metode pembelajaran kooperatif yang cukup banyak diterapkan di sekolah-sekolah adalah Numbered Head Together atau disingkat NHT, tidak hanya itu saja, NHT juga banyak sekali digunkan sebagai bahan penelitian tindakan kelas (PTK). Apa dan bagaimana NHT itu? Bagaimana menerapkannya dan apa saja keunggulannya, baca terus artikel berikut.

Number Head Together adalah suatu Model pembelajaran yang lebih mengedepankan kepada aktivitas siswa dalam mencari, mengolah, dan melaporkan informasi dari berbagai sumber yang akhirnya dipresentasikan di depan kelas (Rahayu, 2006:29).

NHT pertama kali dikenalkan oleh Spencer Kagan dkk (1993:17). Model NHT adalah bagian dari model pembelajaran kooperatif struktural, yang menekankan pada struktur-struktur khusus yang dirancang untuk mempengaruhi pola interaksi siswa. Struktur Kagan menghendaki agar para siswa bekerja saling bergantung pada kelompokkelompok kecil secara kooperatif. Struktur tersebut dikembangkan sebagai bahan alternatif dari sruktur kelas tradisional seperti mangacungkan tangan terlebih dahulu untuk kemudian ditunjuk oleh guru untuk menjawab pertanyaan yang telah dilontarkan. Suasana seperti ini menimbulkan kegaduhan dalam kelas, karena para siswa saling berebut dalam mendapatkan kesempatan untuk menjawab pertanyaan peneliti (Tryana, 2008).

Menurut Kagan (2007) model pembelajaran NHT ini secara tidak langsung melatih siswa untuk saling berbagi informasi, mendengarkan dengan cermat serta berbicara dengan penuh perhitungan, sehingga siswa lebih produktif dalam pembelajaran. 


\section{Langkah-Langkah Model Pembelajaran Kooperatif Tipe NHT}

\begin{tabular}{|c|c|c|}
\hline Tahapan & Kegiatan Guru & Kegiatan Siswa \\
\hline 1. Penomoran & $\begin{array}{l}\text { Guru membagi siswa ke } \\
\text { dalam beberapa kelompok } \\
\text { dengan anggota masing- } \\
\text { masing kelompok } \\
\text { sebanyak 4-6 orang dan } \\
\text { setiap anggota kelompok } \\
\text { diberi nomor } 1 \text { sampai } 6 \text {. }\end{array}$ & $\begin{array}{l}\text { Siswa berkelompok sesuai instruksi } \\
\text { guru. }\end{array}$ \\
\hline $\begin{array}{l}\text { 2. Mengajukan } \\
\text { Pertanyaan }\end{array}$ & $\begin{array}{l}\text { Guru mengajukan } \\
\text { pertanyaan kepada siswa }\end{array}$ & $\begin{array}{l}\text { Menyimak pertanyaan guru dan } \\
\text { Mengerjakan LKS yang } \\
\text { diberikan. }\end{array}$ \\
\hline 3. Berpikir bersama & $\begin{array}{l}\text { Guru memberi kesempatan } \\
\text { Kepada siswa untuk } \\
\text { berpikirbersama } \\
\text { menyatukan pendapatnya. }\end{array}$ & $\begin{array}{l}\text { Siswa berdiskusi tentang } \\
\text { permasalahan yang ada si LKS. }\end{array}$ \\
\hline 4. Menjawab & $\begin{array}{l}\text { Guru memanggil salah } \\
\text { satu nomor tertentu untuk } \\
\text { mempresentasikandi } \\
\text { depan kelas. }\end{array}$ & $\begin{array}{l}\text { Siswa yang dipanggil nomornya } \\
\text { mempresentasikan hasil kerja } \\
\text { kelompoknya, sedangkan siswa } \\
\text { yang lain menyimak dan } \\
\text { menanggapi presentasi. }\end{array}$ \\
\hline
\end{tabular}

\section{Peningkatan Keterampilan Berbicara dengan Menggunakan Metode Numbered Heads Together (NHT)}

Peningkatan belajar keterampilan berbicara sebagai salah satu kompetensi dasar dalam pelajaran bahasa yang perlu ditingkatkan. Untuk itu, penyajian materi dengan metode yang tepat perlu terus diupayakan, salah satunya metode tersebut adalah metode Numbered Heads Together (THT) adalah adalah guru hanya menunjuk seorang siswa yang mewakili kelompoknya tanpa memberitahu terlebih dahulu siapa yang akan mewakili kelompoknya.Cara ini menjamin keterlibatan semua siswa, dan juga merupakan upaya yang sangat baik untuk meningkatkan tanggung jawab

Hal ini dilakukan karena NHT merupakan suatu model pembelajaran yang menekankan belajar dalam kelompok-kelompok yang terdiri dari 4-6 orang siswa yang heterogen, saling membantu satu sama lain, bekerjasama dalam menyelesaikan masalah, dan menyatukan pendapat untuk memperoleh keberhasilan yang optimal baik dalam kelompok maupun individual.

Pembelajaran langsung dengan gaya belajar NHT merupakan model pembelajaran yang banyak dipilih untuk melaksanakan proses belajar mengajar.
Hal ini dikarenakan metode NHT adalah salah satu model pembelajaran yang berguna untuk menumbuhkan kemampuan kerja sama, kreatif, berfikir kritis dan kemauan membantu siswa. Tema yang diajarkan kepada siswa adalah tema yang menuntut siswa untuk menemukan konsep secara kerja sama dengan temantemannya.

Salah satunya adalah pembelajaran keterampilan berbicara. Dalam hal ini selain memahami konsep cara berbicara yang benar, siswa juga dituntut mendiskusikan dan dapat dapat menerapkan untuk dapat menyelesaikan persoalan bahasa Indonesia dengan benar. Diharapkan dengan diterapkannya pembelajaran metode NHT siswa dapat berubah menjadi kreatif dan berfikir kritis dalam mengatasi persoalan-persoalan yang ada. Dari paparan di atas sudah tampak jelas, bahwa metode NHT itu ada pengaruhnya dalam meningkatkan hasil belajar siswa dalam keterampilan berbicara.

Selain dapat meningkatkan hasil belajar siswa dalam keterampilan berbicara, metode NHT juga dapat merubah sikap dan prilaku siswa, sehingga siswa dapat berubah kreatif, berfikir kritis dan menemukan konsep-konsep secara 
kerjasama dengan siswa lain dalam

mengatasi persoalan-persoalan yang ada.

\section{METODE}

Penelitian ini menggunakan desain penelitian tindakan kelas (PTK), yang merupakan bentuk kajian yang sistematis reflektif, dilakukan oleh pelaku tindakan (guru), dan dilakukan untuk memperbaiki

kondisi pembelajaran. Penelitian ini terdiri atas dua siklus, yaitu siklus I dan siklus II. Berikut adalah gambar siklus yang ditempuh dalam penelitian ini.

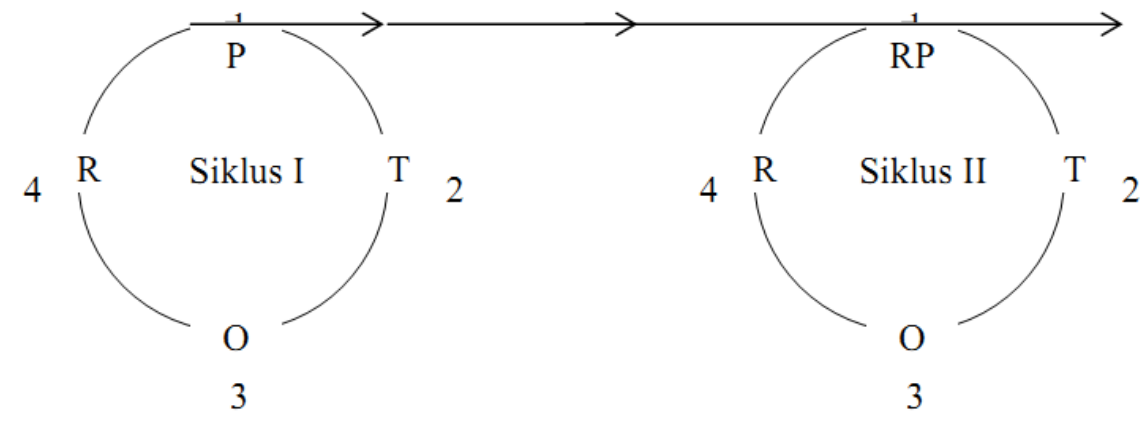

Keterangan :

Gambar 1. Hubungan Siklus I dan Siklus II

$$
\begin{array}{ll}
\mathrm{P} & \text { : Perencanaan } \\
\mathrm{T} & \text { : Tindakan } \\
\mathrm{O} & \text { : Observasi/pengamatan } \\
\mathrm{R} & \text { : Refleksi } \\
\mathrm{RP} & \text { : Revisi Perencanaan }
\end{array}
$$

Tindakan penelitian ini dilakukan dua siklus. Setelah dilakukan refleksi yang meliputi analisis dan penilaian terhadap proses tindakan tadi, akan muncul permasalahan atau pemikiran baru, sehingga perlu dilakukan perencanaan ulang atau tindakan ulang, pengamatan ulang, serta dilakukan refleksi ulang. Siklus I bertujuan untuk mengetahui keterampilan berpidato siswa, dari siklus I dipakai sebagai refleksi untuk melakukan siklus II.

Insterumen penelitian yang digunakan adalah instrumen tes dan nontes. Instrumen tes digunakan untuk mengetahui data tentang keterampilan berpidato. Bentuk instrumen nontes dalam penelitian ini digunakan untuk mengetahui perubahan tingkah laku siswa. Instrumen nontes yang digunakan adalah lembar observasi, dan dokumentasi foto.

Tes yang digunakan untuk mengukur keterampilan berpidato siswa VII-B MTs Nahdlatun Nasyiin Kadur Tahun Pelajaran 2019/2020 terdiri atas 25 siswa.

Tes yang digunakan dalam penelitian ini adalah perintah kepada siswa untuk berpidato. Penilaian yang digunakan dalam berpidato terdiri atas lima aspek, yaitu Intonasi dan jeda, Kesesuaian isi dengan topik, Pelafalan, Gerak dan mimik dan Volume suara.

\begin{tabular}{cllc}
\multicolumn{1}{c}{ Skor Penilaian } \\
\hline $\begin{array}{c}\text { No } \\
1\end{array}$ & Aspek & \multicolumn{1}{c}{ Deskripsi } \\
Intonasi dan jeda & $\begin{array}{l}\text { Pengaturan jeda, tinggi rendah nada, keras } \\
\text { lemah suara, cepat-lambat }\end{array}$ & Jumlah Skor \\
2 & $\begin{array}{l}\text { Kesesuaian isi } \\
\text { dengan topik }\end{array}$ & $\begin{array}{l}\text { Isi pidato sesuai dengan topik yang sudah } \\
\text { ditentukan }\end{array}$ & 40 \\
3 & Pelafalan & $\begin{array}{l}\text { Pelafalan kata secara jelas dan tapat } \\
\text { Keserasian antara ekspresi wajah, gerak, }\end{array}$ & 30 \\
4 & Gerak dan mimik & 20 & 20 \\
\hline
\end{tabular}




\begin{tabular}{|c|c|c|c|}
\hline Volume suara & \multicolumn{2}{|c|}{$\begin{array}{l}\text { sikap, dan ucapan } \\
\text { Keras lemahnya suara }\end{array}$} & \multirow[b]{2}{*}{ Penilaian } \\
\hline \multicolumn{3}{|c|}{ Aspek dan Kriteria Penilaian } & \\
\hline Aspek Penilaian & Kategori Soal & Skor & Kriteria Penilaian \\
\hline \multirow{5}{*}{ Intonasi dan jeda } & Sangat baik & 5 & $\begin{array}{l}\text { - Pengaturan jeda, tinggi rendah nada, keras } \\
\text { lemah suara, cepat-lambat sangat baik }\end{array}$ \\
\hline & Baik & 4 & $\begin{array}{l}\text { - Pengaturan jeda, tinggi rendah nada, keras } \\
\text { lemah suara, cepat-lambat baik }\end{array}$ \\
\hline & Cukup & 3 & $\begin{array}{l}\text { - Pengaturan jeda, tinggi rendah nada, keras } \\
\text { lemah suara, cepat-lambat cukup }\end{array}$ \\
\hline & Kurang & 2 & $\begin{array}{l}\text { - Pengaturan jeda, tinggi rendah nada, keras } \\
\text { lemah suara, cepat-lambat kurang }\end{array}$ \\
\hline & Sangat baik & $31-40$ & $\begin{array}{l}\text { - Isi pidato sangat sesuai dengan topik yang } \\
\text { sudah ditentukan }\end{array}$ \\
\hline \multirow{3}{*}{$\begin{array}{l}\text { Kesesuaian isi dengan } \\
\text { topik }\end{array}$} & Baik & $21-30$ & $\begin{array}{l}\text { - Isi pidato sesuai dengan topik yang sudah } \\
\text { ditentukan }\end{array}$ \\
\hline & Cukup & $11-20$ & $\begin{array}{l}\text { - Isi pidato cukup sesuai dengan topik yang } \\
\text { sudah ditentukan }\end{array}$ \\
\hline & Kurang & $0-10$ & $\begin{array}{l}\text { - Isi pidato kurang dengan topik yang sudah } \\
\text { ditentukan }\end{array}$ \\
\hline \multirow[t]{5}{*}{ Pelafalan } & Sangat baik & $24-30$ & $\begin{array}{l}\text { - Pelafalan kata secara jelas dan tepat } \\
\text { - Pelafalan kata secara jelas }\end{array}$ \\
\hline & Baik & $16-23$ & - Pelafalan kata cukup jelas dan cukup tepat \\
\hline & Cukup & $8-15$ & $\begin{array}{l}\text { - Pelafalan kata kurang jelas dan kurang } \\
\text { tepat }\end{array}$ \\
\hline & Kurang & $0-7$ & \\
\hline & Sangat baik & $15-20$ & $\begin{array}{l}\text { - Keserasian antara ekspresi wajah, gerak, } \\
\text { sikap, dan ucapan sangat baik }\end{array}$ \\
\hline \multirow[t]{3}{*}{ Gerak dan mimik } & Baik & $10-14$ & $\begin{array}{l}\text { - Keserasian antara ekspresi wajah, gerak, } \\
\text { sikap, dan ucapan baik }\end{array}$ \\
\hline & Cukup & $5-9$ & $\begin{array}{l}\text { - Keserasian antara ekspresi wajah, gerak, } \\
\text { sikap, dan ucapan cukup }\end{array}$ \\
\hline & Kurang & $0-4$ & $\begin{array}{l}\text { - Keserasian antara ekspresi wajah, gerak, } \\
\text { sikap, dan ucapan kurang baik }\end{array}$ \\
\hline \multirow{4}{*}{ Volume suara } & Sangat baik & 5 & - Keras lemahnya suara sangat jela \\
\hline & Baik & 4 & - Keras lemahnya suara jelas \\
\hline & Cukup & 3 & - Keras lemahnya suara cukup jelas \\
\hline & Kurang & 1 & - Keras lemahnya suara kurang jelas \\
\hline
\end{tabular}

Nilai yang didapat dari tes akhir siklus 1, dan tes akhir siklus II, kemudian dimasukkan ke dalam tabel kategori nilai.
Berikut adalah tabel kategori nilai yang digunakan.

Rentang Keberhasilan Siswa

\begin{tabular}{ccc}
\hline No & Kategori & Rentang Nilai \\
1 & Sangat baik & $85-100$ \\
2 & Baik & $75-84$ \\
3 & Cukup & $60-74$ \\
4 & Kurang & $0-59$ \\
\hline
\end{tabular}

Instrumen nontes yang digunakan oleh peneliti untuk mengumpulkan data kualitatif, yaitu berupa:
a. Pedoman Observasi
b. Pedoman Angket
c. Dokumentasi Foto

\section{PEMBAHASAN}

Pembelajaran berbicara dengan menggunakan pembelajaran kooperatif metode NHT diawali dengan pemberian tes awal atau yang lebih sering disebut sebagai kegiatan pratindakan. Kegiatan tersebut diadakan untuk mengetahui kemampuan awal siswa dalam berpidato sebelum menggunakan pembelajaran kooperatif metode NHT.

Selain itu, dalam metode NHT hasil tes awal berguna sebagai bahan 
pertimbangan untuk menentukan kelompok dan sebagai dasar untuk mengetahui nilai perkembangan siswa pada pembelajaran berikutnya. Setelah pemberian tes awal, selanjutnya siswa diberikan pembelajaran berbicara dengan menggunakan pembelajaran kooperatif metode NHT tahap pertama atau siklus I dan berlanjut dengan tahap kedua atau siklus II. Pada akhir pembelajaran, siswa diberikan tes untuk mengetahui kemampuan siswa dalam berbicara setelah belajar dengan menggunakan pembelajaran kooperatif metode NHT.

Melalui metode NHT, kelas dibagi menjadi beberapa tim kelompok. Bahan akademik yang disajikan dalam bentuk teks, dan setiap siswa bertanggung jawab untuk mempelajari satu bagian dari bahan akademik tersebut (Nurhadi dan Senduk 2003:64). Begitu pula yang terjadi dengan pembelajaran berbicara menggunakan pembelajaran kooperatif metode NHT pada kelas VII, kelas dibagi menjadi beberapa kelompok, dalam hal ini didasarkan pada kemampuan masingmasing siswa. Bahan akademik yang diajarkan juga berbentuk teks yaitu buku tentang berbicara.
Metode NHT, setiap anggota tim bertanggung jawab untuk mendalami materi pembelajaran yang ditugaskan kepada tiap-tiap siswa kemudian tugas siswa selanjutnya adalah mengajarkan materi tersebut kepada teman sekelompoknya yang lain (Ibrahim 2000:22). Siswa kelas VII mengikuti dengan baik alur pembelajaran berdasarkan metode NHT dan diakhiri dengan tes akhir. Berikut adalah tabel hasil nilai rata-rata tes siswa kelas VII pada saat siklus I, dan siklus II beserta hasil peningkatannya.

\section{Hasil Penelitian Pra Siklus}

Hasil tes pratindakan merupakan hasil tes siswa dalam keterampilan berbicara sebelum menggunakan pembelajaran kooperatif metode NHT. Kegiatan pratindakan ini menggunakan lima aspek penilaian, yaitu yaitu Intonasi dan jeda, Kesesuaian isi dengan topik, Pelafalan, Gerak dan mimik dan Volume suara. Aspek tersebut adalah aspek yang sama yang akan digunakan untuk menilai kemampuan siswa dalam keterampilan berbicara pada siklus I dan siklus II selanjutnya.

Hasil Tes Keterampilan Berbicara Siswa Prasiklus

\begin{tabular}{lllccccc}
\hline \multicolumn{1}{c}{ Noma } & \multicolumn{5}{c}{ Aspek Penilaian } & \multicolumn{2}{c}{ Nilai } \\
1 & Aditama Riskianto & $\mathbf{1}$ & $\mathbf{2}$ & $\mathbf{3}$ & $\mathbf{4}$ & $\mathbf{5}$ & \\
2 & Agung Dwi Cahyono & 2 & 20 & 20 & 15 & 4 & 61 \\
3 & Agus Wahyudi & 2 & 20 & 20 & 15 & 4 & 61 \\
4 & Ahmad Fauzan & 3 & 20 & 20 & 10 & 4 & 57 \\
5 & Ainur Rasyid & 2 & 25 & 15 & 15 & 3 & 60 \\
6 & Akhmad Syarifuddin & 2 & 20 & 19 & 15 & 4 & 60 \\
7 & Aminatus Zahroh & 2 & 15 & 20 & 10 & 4 & 51 \\
8 & Andi Efendi & 3 & 20 & 18 & 15 & 4 & 60 \\
9 & Arfan Febriyanto & 2 & 20 & 17 & 15 & 4 & 58 \\
10 & Dani Darmawan & 2 & 20 & 18 & 10 & 4 & 54 \\
11 & Dedy Yuli Harisma & 3 & 23 & 20 & 15 & 4 & 65 \\
12 & Deni Hermawan & 2 & 24 & 15 & 10 & 3 & 54 \\
13 & Desi Malinda & 3 & 20 & 20 & 15 & 3 & 61 \\
14 & Desi Wulandari & 3 & 20 & 20 & 15 & 3 & 61 \\
15 & Fifin Nurkori' Ah & 2 & 20 & 20 & 15 & 4 & 61 \\
\hline
\end{tabular}


p-ISSN: 2503-1228; e-ISSN: 2621-4172

\begin{tabular}{llcccccc}
\hline 16 & Hendra Susanto & 3 & 30 & 15 & 10 & 4 & 62 \\
17 & Imam Jufriadi & 3 & 20 & 15 & 15 & 4 & 57 \\
18 & Imam Sutrisno & 2 & 20 & 25 & 10 & 3 & 60 \\
19 & Kiki Ramanda Sukma & 2 & 25 & 25 & 10 & 4 & 66 \\
20 & Maya Anggriani YP & 2 & 20 & 15 & 15 & 4 & 56 \\
21 & Miskanah & 2 & 25 & 15 & 15 & 4 & 61 \\
22 & Moh Aziz & 2 & 20 & 20 & 10 & 3 & 55 \\
23 & Moh Helmi Kusnadi & 2 & 24 & 20 & 15 & 4 & 65 \\
24 & Moh Safaul Hafifi & 2 & 25 & 15 & 15 & 4 & 61 \\
25 & Moh Salehoddin & 2 & 20 & 15 & 15 & 4 & 56 \\
& $\quad 58$ & 536 & 467 & 330 & 94 & 1485 \\
\hline
\end{tabular}

Berdasarkan sajian data tersebut, maka deskripsi hasil tes pada siklus I berikut ini:

Rekapitulasi Hasil Tes Berpidato Siklus I

\begin{tabular}{llccccl}
\hline No & \multicolumn{1}{c}{ Kategori } & Nilai & F & $\begin{array}{c}\text { Bobot } \\
\text { Nilai }\end{array}$ & $\begin{array}{c}\text { Persen } \\
(\%)\end{array}$ & Rata-rata Nilai \\
1 & Sangat baik & $85-100$ & - & - & 0 & 1485 \\
2 & Baik & $75-84$ & - & - & 0 & $=\frac{15}{25}$ \\
3 & Cukup & $60-74$ & 16 & 987 & 64.00 & $=59,4$ (kurang) \\
4 & Kurang & $0-59$ & 9 & 498 & 36.00 & \\
& Jumlah & & 25 & 1485 & 100 & \\
\hline
\end{tabular}

\begin{tabular}{rccc}
\multicolumn{4}{c}{ Perbandingan Nilai Hasil Tes } \\
\hline Hasil & Nilai Rata-rata Siklus & Nilai Rata-rata Siklus II & Peningkatan \\
& I dalam \% & dalam \% & dalam \% \\
Persentase & 64.88 & 80.00 & 15.12 \\
Kategori & Cukup & Baik & Baik \\
\hline
\end{tabular}

Berdasarkan data diatas dapat diketahui bahwa nilai rata-rata kelas dalam persen pada saat siklus I adalah $64,88 \%$ dengan kategori cukup. Setelah dilakukan pembelajaran membaca intensif buku biografi tokoh menggunakan pembelajaran kooperatif metode NHT siklus II, nilai rata-rata siswa meningkat menjadi $80,00 \%$ dengan kategori baik. Bila diselisihkan, nilai rata-rata tersebut mengalami peningkatan sebesar $15,12 \%$ dan dapat diketegorikan peningkatan yang baik. Tindakan siklus II diadakan guna memperbaiki nilai-nilai siswa yang masih berada di bawah kriteria ketuntasan minimal yang diharuskan. Selain itu, tindakan siklus II juga diberikan untuk membiasakan siswa dalam berpidato dan memahami isi dari pidato tersebut

Tidak berbeda dengan siklus I, hasil tes siklus II juga diperoleh dari keseluruhan jumlah skor tiga aspek keterampilan membaca intensif buku biografi tokoh yang diujikan, yaitu (1) menyarikan riwayat hidup tokoh, (2) menyebutkan keistimewaan tokoh, dan (3) menemukan hal-hal yang bermanfaat bagi siswa dari buku biografi tokoh. Berikut adalah tabel peningkatan nilai tiap aspeknya. 
Peningkatan Nilai Rata-rata Tiap Aspek

\begin{tabular}{clccccc}
\hline No & \multicolumn{1}{c}{ Aspek } & $\begin{array}{c}\text { Rata-rata } \\
\text { Siklus I }\end{array}$ & Kategori & $\begin{array}{c}\text { Rata-rata } \\
\text { Siklus II }\end{array}$ & Kategori & Peningkatan \\
1 & Intonasi dan jeda & 67.20 & Cukup & 82,40 & Baik & 15,2 \\
2 & Kesesuaian isi & 61.70 & Kurang & 77,40 & Baik & 15,7 \\
& dengan topik & 66.27 & Cukup & 82,14 & Baik & \\
3 & Pelafalan & 66,00 & & 78,00 & Baik & \\
& Gerak dan mimik & 75,20 & Cukup & 86,40 & Baik & \\
& Volume suara & & &
\end{tabular}

Berdasarkan tabel 5.2 diketahui bahwa pada aspek intonasi dan jeda, kemampuan siswa mengalami kenaikan. Dimulai dari pada siklus I rata-rata nilai aspek intonasi dan jeda sebesar 67.20, sedangkan pada siklus II sebesar 82,40. Hal tersebut mengindikasikan bahwa sebagian besar siswa telah mampu berpidato dengan intonasi dan jeda dengan baik.

Aspek penilaian yang kedua adalah kesesuaian isi dengan topik. Nilai siswa untuk aspek kesesuaian isi dengan topic juga mengalami peningkatan pada tiap siklusnya. Pada saat siklus I rata-rata nilai siswa 61,70 , dan pada siklus II meningkat menjadi 77.40. Hal tersebut menunjukkan bahwa pada siklus II, seluruh siswa sudah mampu berpidato dengan aspek kesesuaian isi dengan topik.

Pada aspek ketiga, nilai rata-rata siswa selalu mengalami peningkatan, namun demikian pula pada aspek pelafalan. Nilai pada siklus I menjadi 66,27 , mengalami peningkatan pada siklus II, menjadi 82.14.

Pada aspek gerak dan mimik nilai rata nilai siswa selalu mengalami peningkatan. Nilai pada siklus I menjadi 66,00 , mengalami peningkatan pada siklus II, menjadi 78.00.

Pada aspek volume suara nilai rata-rata siswa juga mengalami peningkatan. Nilai pada siklus I menjadi 75,20 , mengalami peningkatan pada siklus II, menjadi 86.40.

\section{Hasil Observasi Aktivitas Siswa}

Analisis hasil nontes meliputi hasil nontes yang diperoleh selama pembelajaran siklus I dan siklus II. Hasil nontes dapat digunakan untuk mengetahui seberapa jauh perubahan tingkah laku yang dialami oleh siswa kelas VII setelah mengikuti pembelajaran pidato menggunakan pembelajaran kooperatif metode NHT siklus I dan siklus II. Hasil nontes tersebut meliputi hasil yang diperoleh melalui observasi. Berikut adalah analisis hasil nontes yang diperoleh selama pembelajaran siklus I dan siklus II.

Observasi dilaksanakan selama pembelajaran pidato dengan pembelajaran kooperatif metode NHT pada siswa kelas VII berlangsung. Observasi dilaksanakan oleh peneliti yang sekaligus bertindak sebagai guru dengan bantuan seorang teman dan guru mata pelajaran. Aspek yang diamati dalam observasi meliputi enam perilaku siswa, baik positif maupun negatif yang muncul selama pembelajaran berlangsung. Aspek-aspek yang diamati tersebut adalah(1) keseriusan siswa dalam mengikuti pembelajaran, (2) keaktifan siswa dalam bertanya, berkomentar, atau menanggapi, (3) ketertarikan siswa terhadap metode yang diterapkan yaitu metode NHT, (4) sikap siswa ketika membaca, (5) keaktifan siswa dalam kerja kelompok.

Selama pembelajaran siklus I dan siklus II berlangsung, banyak aktivitasaktivitas siswa baik itu positif maupun negatif yang ditangkap oleh peneliti. Setelah peneliti melakukan analisis, antara siklus I dan siklus II, siswa mengalami berbagai perubahan sikap ke arah yang 
lebih baik. Pengalaman yang diperoleh siswa pada pembelajaran siklus I memberi banyak perubahan, terutama perubahan tingkah laku siswa, terutama ketika siswa bekerja dalam kelompok. Hal tersebut sesuai dengan salah satu tujuan penting dari pembelajaran kooperatif yaitu untuk mengajarkan keterampilan kerjasama dan kolaborasi. Keterampilan ini amat penting dimiliki dalam masyarakat di mana banyak kerja orang dewasa sebagian besar dilakukan dalam organisasi yang saling bergantung satu sama lain dan di mana masyarakat hidup semakin beragam secara budaya (Ibrahim 2000:5-9).

Dengan menggunakan pembelajaran kooperatif metode NHT, siswa dilatih untuk dapat bekerjasama dengan semua siswa. Selain mendapat

\section{KESIMPULAN}

Hasil aktivitas siswa selama pembelajaran siklus I dan siklus II berlangsung, banyak aktivitas-aktivitas siswa baik itu positif maupun negatif yang ditangkap oleh peneliti, antara siklus I dan siklus II, siswa mengalami berbagai perubahan sikap ke arah yang lebih baik. Pengalaman yang diperoleh siswa pada pembelajaran siklus I memberi banyak perubahan, terutama perubahan tingkah laku siswa, ketika siswa bekerja dalam kelompok.

Dari hasil penyebaran angket tentang model pembelajaran yang digunakan guru dalam pembelajaran berpidato dengan metode NHT pada siklus I. Mereka menjawab dengan rata-rata tidak senang. Sedangkan pada siklus II rata-rata siswa sudah berpendapat sangat senang

\section{DAFTAR PUSTAKA}

Tarigan, H.G. 1987. Berbicara Salah Satu Keterampilan Berbahasa. Bandung: Penerbit Angkasa. kemudahan menyelesaikan tugas akademik yang diberikan yaitu memahami pidato, siswa juga belajar bekerjasama dan berkolaborasi untuk dapat menyelesaikan tugas tersebut. Terlebih lagi, metode NHT mengajarkan siswa untuk bekerja dalam dua jenis kelompok yang berbeda dengan tugas yang berbeda pula dalam satu kali pembelajaran. Siswa yang pada awalnya memiliki sifat individualisme yang tinggi mulai dapat bekerjasama dan dapat saling menghargai satu sama lain. Selain itu, ada juga beberapa perubahan tingkah laku yang lain dari siswa selama kegiatan belajar mengajar, seperti lebih memperhatikan, lebih aktif bertanya, dan sebagainya.

karena merasa cocok dengan metode pembelajaran NHT. Dengan demikian pembelajaran keterampilan berbicara pada siklus II sudah baik sehingga tidak perlu melakukan tindakan siklus berikutnya.

Terdapat peningkatan keterampilan berbicara. Melalui tes pada prasiklus diperoleh hasil 59,4 kemudian nilai tes siklus I mengalami peningkatan diperoleh nilai rata-rata hasil tes siswa kelas VII secara klasikal adalah 64,88 dengan kategori cukup. Meskipun hasil tersebut sudah cukup, namun peneliti masih melaksanakan pembelajaran dan tes siklus II hingga diperoleh hasil rata-rata klasikal untuk tes siklus II yaitu 80,00 dan berada pada kategori baik, dengan peningkatan sebesar $15,12 \%$ dari hasil tes siklus I dan peningkatan tersebut berada pada kategori baik.

Depdikbud, Kamus Besar Bahasa Indonesia, Jakarta: Balai Pustaka, 2002

Undang-undang RI No. 20 Tahun 2003 Tentang Sistem Pendidikan 
Reforma: Jurnal Pendidikan dan Pembelajaran Vol. 9 No. 1 (2020) p-ISSN: 2503-1228; e-ISSN: 2621-4172

Nasional, Jakarta: Kloang Klede, 2003

Ibrahim, Muslimin, dkk. 2006. Pembelajaran Kooperatif. Surabaya: University press.

Kagan. 2000. Cooperative Learning Structure. Numbered Heads Together, (Online),(http://Alt.Red/clnerwork/n umbered.htm, diakses 5 Desember 2007).
Kagan. 2007. NHT, (Online) (http://www.eazhull.org.uk/nlc/numb ered_heads.htm, diakses 5 Desember 2007)

Rahayu, Sri, Online: diakses 4 Januari 2009,

(http://pelawiselatan.blogspot.com/2 009/03/number-head-together-html)

Tryana, Antin. 2008. Penerapan Model Pembelajaran Kooperatif Numbered Heads

Together

(Nht) 